\title{
中 世広場
}

\section{渡辺達 三}

\section{The Square in the Middle Ages}

\section{By Satomi WATANABE}

\section{1. 序}

本論は主として中世の集落・地域社会の広場について 考察を試みたものである。ここに集落・地域社会の広場 とは、生産・生活上の其间性の積極的な実現の場である 集落・地域社会の構成員が、そのような共同性を実現す る一の手段として、あるい哇その絬果として、彼らの日 常的小生活圈のうちに文として彼らを中心利用する厇 場である。

しかしそのような资の広場法、中情において洁、その 侍代の極限である惣村・佨町絬命がなされるにいたる室 町期以降に颃いてしかみることができない。さらに㛜密 に注、そのような絬命扔いても、それから蹯外される 埭属的農民・町民か引籍に存在し集落・地域社会構成員 全員の自由に参加することのできる広埸は、一般湖ては みることができない。

中世においても庄場恃集落・地域社会の構成員に上! 彼らのために設けられるのではなく、領卡・土豪似名主 ・門閥的特権町民などによりつくられた空間を庶民が またま利用するという形態が一般的である。だ、号の 上うな空間の彼らへの解放度、彼らの利月のしかた结时 代の進展ととも江次第汇発展していくのであり、中爿の 一般㑬な姿在嗸止的にとらえることはできない。たと光 ば中世期の小社寺数の䏴加に警くべきものがあるが、 そのような空間の成立は地縁的村落・都市其间体的な基 盤をもつ集落・地域社会の形成・発展と大きな相関を有 し、それらのうちには废場としての性格が一定度みられ るものも少くない。

以上のような理解を念䫓におきながら、2で中世の妄 場在成立させる社会経济的な基盤の推移と広場との関係 をみ、3で2、30空間について広場的な性格かいかにそ の空間のあるいは機能上の特性を媒介としながら形成さ れていくか、ないしはその性格をみ、别稿でいくつかの 集落における広場の存在態梯をみるのがこの小諭の淉題 である。

な抢本稿のなるにあたり建筑評論家伊藤鄭爾、千代田 区立図書館鈴木昌雄の各位上り多大な御教示を元た。厚

東京大学園芸第 2 研究室
く㴬意を肌しのべる。

1) 渡辺洼三：『中惜藮落の広埸』（「造園雑誌Vol. 34 No. 4)

\section{2. 中世社会の推移と広場}

ここで中世と法荘園制の成立期から近世幕藩体制の成 立直前までの時代とする。中世效䩮の農奴への進化を 遂げつつある時代としてとらえることができる。家父長 制の構造をもつ名体制结太賙検地の過程を経て法じめて 根柢的に否定されるのであり、中世扔いては、その極 限に進展し太閤㭘地がそれをもつて新たな統法のための 下部機構として捉㫕て惣村においてさえも在家・下人・ 所徒等と称される自立を遂げていない赫属的な首を多く その内に包含していた。それ的光中世にわいては農奴= 封建的小農民が村落共同体の構成員となるところの封建 村落共闰体をみること法できない。中世村落の基本的構 造・性格法一定地域間の名主の相互間にとり絬ばれる諸 関係の側面においてしかるることができないのである。 それも名の規模が比輍㑬小さく名の構造が多かれ少なか れ人組錯闲関係存寻つ畿内及びその周过の埸合に限られ 西国・東国等の辽境地域の上うに名の規模が大きく名の 構成がそのうちに山林・原野・水源古包含しそれ自身で

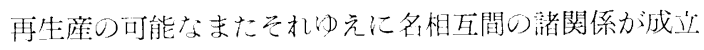
しえず孤立的である場命に法名主相互間の共同体的諸関 係の存在の必然性を推测することができない。いずれに しても在家・下人・所従等の隷属的生産者は小農民とし ての自立が確保されないうちは領主・名主を媒介として しか自己を実現するととができないのであり、その身柄 さえも彼らに䍮属する直接生産者相互間们ける地緑的 ・社会的諸関係の存在を推定することはできない。この ような段階においては領主・名主その他の支配的階首の 空間在䍮属的農民が一時的・日常的飞、個別的 - 集団的 に利用するととがあつても彼等相互間に法何らの共同性 の契機の生じない領主・名隹に隷属する一隷属民あるい 仗たんにそれらの偶然的な集命による利用化すぎず、生 産・生活の地緑的村落を共通にし生活感情をともにつ相 互に連帯惑ある人々の広場としての性格を有する空間で はありえない。 
しかし、着実な生産力の增大ととも荘園体制をきり くずしていく地緑的村落の発展を特代の進展とともにみ ることができる。そ机忧ず名主关の性格変化、その菲 域をこえる結合による菲園領主势小と守紧地頭勢小の排 除にみることができる。このような段階においては、社 寺の境内地もそれらの名主の絬合の核、あるい証り・ 集会の場としての性格をもつにいたる。荘園制の形成期 においては式内社のごとく以前からあり、国家鎮洲的性 格を残存させている神社、荘園領主が新たに衔請した神 社いずれも荘園領主の所有に属するものが多く菲の鎮守 として機能したのであるが、荘園制が放ざ、名主閒の 地緑的・同族団的諸関係が生ずるやこの鎮守はそのよう な名主圈の絬合の空間として変質する場命がある。それ

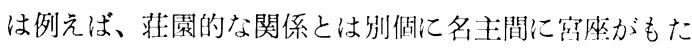
れるような場合と刘応する。近汇多賀社の宮座がその顽 役奉仕の制において郡を単位としてなされたり、大和の 大安寺八幡宮の場合には、その祭礼の頭役を勤》る八条 郷が辰市四侗郷の随一であつて大安寺の所領ではなく明 応元年 8 月大安封がこれを自専すべき旨要求したさい、 尋尊が祭の頭役の勤仕注自専の訨文に非ず、検断等は一 切唇市郷の例に従うべきであると述べていたりするにい たる。このようなケースは、荘圆鎮守神内に置かれてい る土地が別の荘園の領土にあるような散在入組型の荘園 においては現象としては特に顕著にあらわれるであろ う。

名主の結命仙畿内及びその周辺では地緑的結合たる性 格を、辺境の場合には等領制的構造をもつ同族団的絬合 たる性格をもつていた。地緑的絬合はその範用力归来の 荘城を超える別個のものとしてあらわれ、それは地下請 ・百姓請の成立および本名主層と小名主職所有者、さら にその下の名主職を所有しない直接生産者首の形成の招 来と対応している。

直接生産者の生活・生産のための共同の基盤としての 村落は上凰名主層の地域的同族団的要求よりなる党・D 癸・国の諸結合の地域の内部成熟してくる。それの一 般的形成の姿注近世以降汇みられるのであるが、南北朝 から室町期にかけて畿内及びその周辺の先進地帯では惣 に典型的にみられるような小農民の独立の進行の過程で 徐々にあらわれてくる農業生産の進展と生活維持の社会 的連関のなかで生じる下級名主屏・小農民の地域的絬合 をみるととができる。表一1は中世の社寺数の動態を示 したものであるが、社寺数とくに神社の增加には顕著な ものがあり、てれはそのような地域的村落の形成と刘态 するものであると考えられる。

そこでは荘園制内部における名主以下の層の違いを反咉 した身分差を濃厚に残し、それは祭礼・窝座などの神事 さらに制の運営そのもののなか生きていだ。しい、
表一1 中世社寺動態一建筑遗構にみる—

\begin{tabular}{|c|c|c|c|c|c|}
\hline \multicolumn{2}{|l|}{ 地方别 } & $\begin{array}{c}\text { 鉡畣時代 } \\
\text { A }\end{array}$ & $\frac{\text { 室町時代 }_{\mathrm{B}}}{}$ & $\begin{array}{l}\mathrm{B} \\
\mathrm{A}\end{array}$ & 神社: \\
\hline \multirow{2}{*}{ 五. 畿 内 } & 神社. & 21 & 67 & 3.2 & \multirow{2}{*}{3.8} \\
\hline & 寺院 & 93 & 78 & 0.8 & \\
\hline \multirow{2}{*}{ その他 } & 神社: & 35 & 167 & 4.8 & \multirow{2}{*}{1.9} \\
\hline & 寺院 & 73 & 184 & 2.5 & \\
\hline \multirow{2}{*}{ 部(全闻) } & 神社 & 56 & 234 & 4.2 & \multirow{2}{*}{2.6} \\
\hline & 寺院 & 166 & 262 & 1.6 & \\
\hline
\end{tabular}

自站可能な小農民首の存在が広箸にみられるような先進 怱村の場合に岋窝座なども次第にそのような小農層に開 放されつつあつた。それは、有力な名主が武士として早 期上:界離村し、散在耕地が一円化され、さらに戦乱によ る自衛、領主に対するた制の対抗于役などの必要が生じ 戦略上、村落が一体となつて絬束を図らなければならな い上うな地域において、とくに顕著にみられるようにな る。そのような場合には、ほとんど全村民ともいつてよ い人々の共同体的関係が成立し、そのような人々の精神 的核・集会所としての広場的空間が成立するであろう。

中世村落の神社の性格変化は、先進的、後進的な発展 をとげている地帯によつて著しく異り、一般的な規定を することはできないが、時代の大きな動きのなかでその

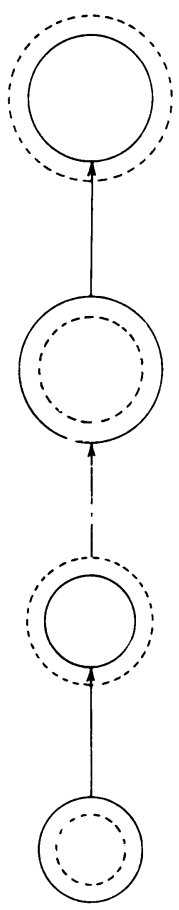
主流を図一1の上うに模式的に概括する ことができると考えられる。

$\square$ 口世第 1 期

国家鎮護的性格を失い、荘園領主の所 領支配上の機能が実体化する

〔式内社から荘園鎮守社への変質、菲 園鎮守社の新たな設置了

$\square$ 中世第 2 期

荘園鎮守社䎲名主間結合の核・集会の

場としての機能が芽生える

$\square$ 中世第 3 期

荘園鎮守社としての機能か溺められ名 主間結合のそれが実体化する

〔荘園鎮守社の変質、名主間結合の場 としての新たな神社（中・小社）の設 置]

$\square$ 中世第 4 期

名主間絬合の神社に直接生産者間の結 合・集会・レクリエーションとしての

機能が牙生える

図一1 中世神社の州格変化 
以上たまたま村落の神社について考察したのである か、同様なことは、中期以降その数を増加させつつあつ た都市の神社についてもみられる。また、神社境内地の 集落・地域社会の共同体的な基盤を有する広場的性格は 第 4 期においてはじめて、一般的にはその牙生えを、先 進地帯においてはそれの小社における実体化された姿を みることができるが、このことは神社に限らず、多かれ 少なかれ広場的な性格をもつにいたる他の空間について もいえると考えられる。

1）安良城盛昭：『太閤検地の歴史的前提』（「歴史 学研究」No. 163, 164)

2)，3）永原慶二：『荘園制度支配と中世村落』（「一 橋論叢」Vol.47 No. 3)

4),6), 7), 10）古島敏雄：「日本農業史」岩波畫店、 1956

5）豊田武：『中世に於ける神社の祭祀組織について』 (「史学雑誌」Vol. 53 No. 10,11)

8）拙稿「広場の歴史的研究」（修士論文）において 集村化による地緑的村落の形成の核として小社寺か 機能し成立する過程を島田次郎「日本中世村落史の 研究」の業績より考察している。

9）太田博太郎『日本建築史中世神社』（「建築学大 系日本建築史」彰国社1957）の表に加筆。

\section{3. 中世広場の諸形態}

中世においても広場がそれ独自の空間として実体とし て成立し発展することはなかつた。社寺境内地、市場、 馬場等が広場を必要とし成立させるような一定の社会的 条件の成熟の基盤のうえに、広場的な機能をも併せもつ 空間として存在したにすぎない。しかも、それは、それ ゆえに何らかの形態変化をもたらすという点は管見では 認められない。また、それは、それ本来の機能を減じ、 そのためにその存在理由がなくなるとき、付加的な広場 的機能か作用していてもその存在の姿を失うのである。 実体をともなわない日本の広場はそのような存在基盤の 脆弱さを常にはらんでいたといわなければならない。

中世においては共同体的な基盤を有する広場は一般的 には認められない。ただ時代の進展とともに、より強く 共同的な契機を有する集落・地域社会の広場的空間がみ られるにすぎない。以下それらのいくつかについて若干 の考察を試みてみたい。

\section{i ）街区内中庭広場}

中世から近世初頭にかけて、町屋に团繞された街区の 内に中庭が設けられ、そこが当該街区の人々の広場とし ての性格を一定度有することが推定されるが、このよう な空間を街区内中庭広場と名づけるものとする。
図一 2 は町田家本洛中洛外図姩風の戦国期のたちうり 町の景観を示したものであるが、街区内中庭広場の一の 典型をみせている。他の該当部分などをみあわせてみる と、中庭には共同便所、物干場、水飲場などがあり、街 区内の人々の日常生活と緊密に結びついた接触の場とな つているととの可能性が考えられる。

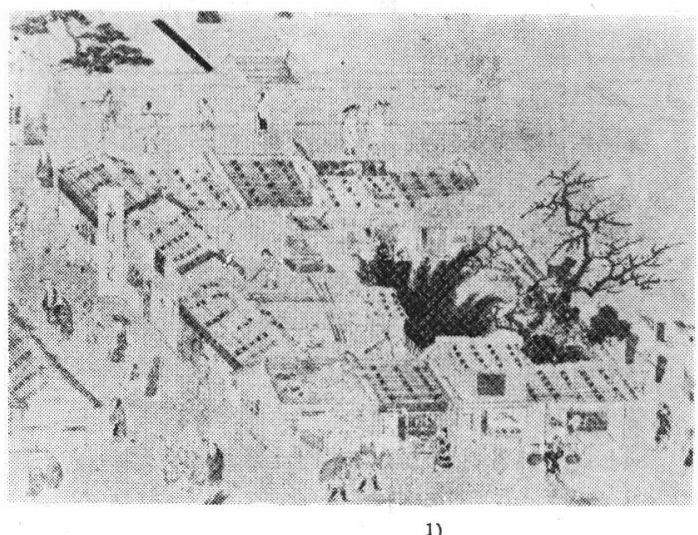

図一2たちうり町付近

このような街区内広場は上向的な発展を遂げつつある 南北朝・室町期の町人自治の日常的なコミュニケーショ ンの一の基盤としての、あるいはそれの実践される舞台 としての広場として重要な機能をになつていたと考えら れる。しかし街区内中庭広場はあくまで共同の庭として の性格か強くつぎのように広場としては一定の限界を有 していたと推測される。

イ.中庭は多くの場合建築物に完全に囲繞され、街路 との連絡が断たれ、街路、他の街区に対し閉鎖され 孤立している。

口. 中庭での人々の接触は各家の私的な生活を遂行す るうえでの偶然的なそれであり、公共生活実現のた めのそこでの自治的・政治的な接触・集会は、中庭 の利用者が主として家事の雑務にかかわる婦人、下 人あるいはそこを遊び場とする子どもたちであるこ となどから成立しにくいと考えられる。

八. 街区それ自体が一自治組織体としての実体もつこ とが比較的少ない。京都の場合についてみると南北 朝期までは坊保とくに保が中世的に編成替省されな がら幕府の被支配機構の媒介環とされるほどの実体 を有する生活の共同の最小の組織体となり、また南 北・室町期以降には街路をはさみ相互に向いあう煩 の集合か町あるいはそれの惣町として㬰体ある生活 共同組織体としてより重要になる。後者の場合には 中庭を囲繞し 1 街区を構成する 4 つの煩はそれぞれ 別の町に属する場合がより一般的となり、公共的・ 自治的生活のうえでの中庭の広場としてのになえる 
機能には限界があり、さらにイのように中庭が街区 に閉鎖されている場合、その限界はさらに大きくな る。このような場合にはむしろ煩にはさまれ煩を結 合させる街路が機能的には広場としての性格をより 強く有するものであつたと考えられる。

1）洛中洛外図屏風部分 町田満次郎氏蔵

2）横井清 : 『町の景観と構造』（京都市「京都の歴 史」3, $1968 \quad 72-90$ )

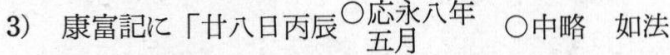
経幡エリ物等、六角堂法師調進之間、三条面惣四町 町、可知行由、被仰出云々」とあり、六角堂頂法寺 が足利義満から「三条面㥎四町町」の知行を得たと とを知りうる。この四町町は三条大路をはさみその 南北に面する室町小路一鳥丸小路一東洞院大路一高 倉小路一万里小路に区割される 4 つの町を意味する と考えられる。こてでは三条大路をはさむ北煩と南 煩とが一体となつて 1 つ町を形成し、それらが4 つあつまつて惣四町町を形成していたてとを知りう る。「煩」は街区の中庭からではなく、街路よりみ るときに生じる用語であり、そのような煩を結合さ せる街路の意義は大きい。なお「煩」は「高倉棧敷 四条高倉與万里小路間北煩有之、浄居庵巴下皆令見 物給者也」（康富記応永 29 年 6 月 7 日の条）、「土 郷門鳥丸南西煩宿所也」(同豪吉 2 年 6 月 11 日の条) $「$ 正親町室町與一条間東煩可為御所之由」（同 3 年 8 月28日の条) 等と康富記、東寺百合文書などの文 献の上にも室町期において頻繁にみられるようにな る。

\section{ii）馬場}

京都・奈良などの大都市においては、京都薄馬場、左 右近馬場、崇徳院馬場、奈良天満宮馬場など、馬場は相 当な数と面績があり、それらのうちには、地域住民の集 会・レクリェーションの空間としての機能を併せもつも のもあつた。

他の多くの空間同様、馬場も元来は庶民の自由に使用 しうる性格の空間ではなかつた。とくに中世期前半にお いてはその性格か漒かつたと考えられる。図一 3 は平安 末期頃の京都の右近馬場における 5 月の騎射天覧の式の 武人の練習風景の部分であるが、それを見物しようとし て群集した人々が神人から追いたてられ遠慮がちに見物 しなければならなかつた様子がうかがえる。

てのような馬場にも室町期頃からつぎにみるように庶 民の一定度の集会・レクリエーションの空間となつてい るものも梕められる。

去十九日太閤・前殿両御所山名申入于犬馬、場以若衆 犬射之、懸御目云々。

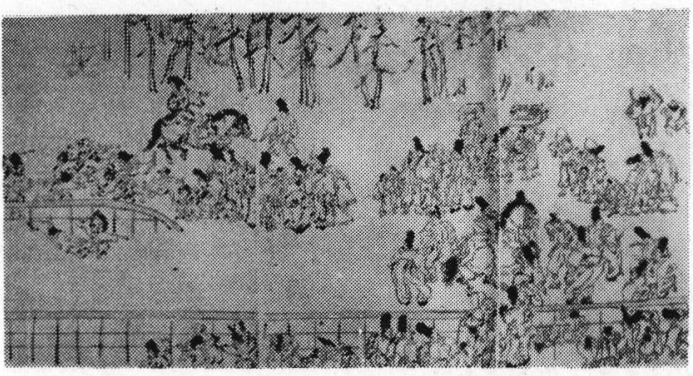

図一3 右近馬場騎射天覧式練習風景

於東馬場鳥合在之云々、越智以下国衆罷出、古市之西 興行也云々

これは奈良の犬馬場、東馬場における犬射、鳥合せの例 である。

図一 4 は宮馬場附近の図である。宮馬場は奈良の中心よ りはずれ南側にある。南北約 $100 \mathrm{~m}$ 、東西約 $60 \mathrm{~m}$ の長方 形であり、馬場から北方上方に天満社が臨まれる。これ

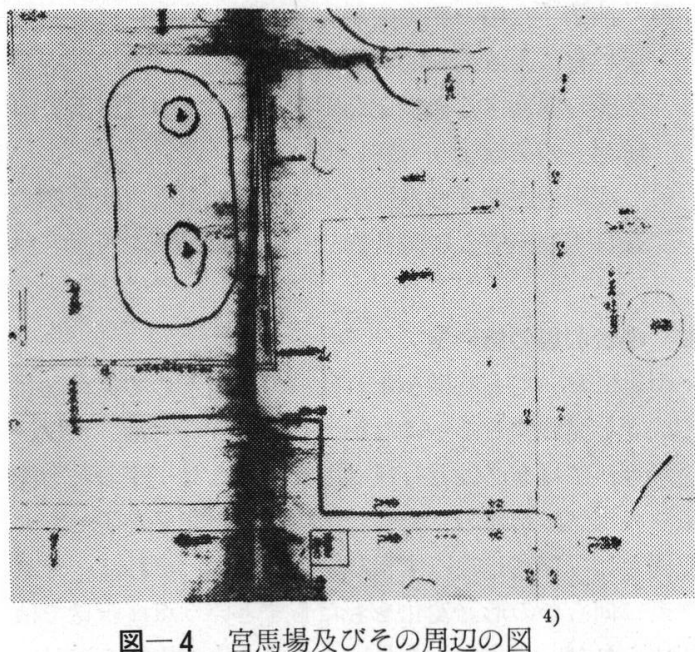

は奈良南北郷民及びその周辺の人々の集会・レクリェー ションの場として機能した。

南北郷民等於馬場院相撲在之、百廿番之内、近来荒郷 共有之、別在所 $\ni$ 相加或増番数云々、奈良中令落以外 事也、当年発手北郷二相当、両方各度也云々、文明四 年五月廿一日相撲打勝在之、其後八又当年在之、就中 次第事仰沙汰衆召寄写之、強杉原折紙二枚続之○下略 てれは奉納の相撲会である。つぎは同馬場における祈雨 主願の猿楽の催しの計画である。南北の郷民がその費用 として相撲銭をあてようとしているのがみえる。

明日馬場殿祈雨之主願猿楽可有之、南北鄉民相撲銭為 猿楽禄物出之、其儀如例也、就其御童子 - 力者等此代 物出之事、郷民等雖訴甲入不出之間、如先規可閣旨披 露之、致去文明二年願能、於御童子・者者不出之旨 且可糺明旨仰了、仍衆中返事閣之旨会申、珍重々々、 
御力者・御童子相撲銭可閣申旨、御披露候、得其覚 悟候、可如下知旨之由、可然様可有御披露旨評定候 也、恐々謹言

$$
\text { 十月廿八日 }
$$

沙汰衆等兼與

按察寺主御房

福智院殿坊地可有相撲銭之由相触之間、先日新儀沙汰 難義旨披露之、仍無為不及催促者也

そして翌日つぎのように実行された。猿楽は今晴座、金 鋼座、法生座の 3 座あり、仮屋が設けられ、正面に衆中 左右に学道以下が並んでいたてとなどを知りうる。

馬場院立願猿楽在之、今晴座・大蔵懃之、金鋼座丈夫 法生座子息夸夫息以上三座也、観世先日路次マテ下向 今日不参、其故八、於細川方公私之芸能近日連続指合 之間、不下罷云々、近日細川方事之間、寺門怱別不及 是非沙汰䩂、凡不得其意者也、郷銭八四座分习支配三 座與、沙沃衆中八貫給之云々、三輩裹頭二テ著座云々 假屋如後日正面衆中、左右学道以下、中綱・仕丁出仕 大綱如薪時令下知之、

假屋修理目代沙汰、諸不守共罷出テ致其沙汰、今日床 敷之云々、凡新儀與、目代又不申是非與、如何、十五 番芸能云々、

また、馬場には、つぎのように、祭礼の仮屋が設けられ るとともあつた。

若宮祭礼馬場假屋事、諸座番匠役也

御殿 寺座番匠 御供所 同 競馬屋 同

正面之西中門吾師綱所军口座番匠

同東中門寺漦座一乗院座

東楽屋 大宅寺本座番匠

西楽屋同新座番氒

これにより祭礼の馬場などにおける催し物、参加者など ある程度うかがい知るととができる。さて、その馬場の 仮屋設置も、つぎのように、進官領が越智方に押領され 材木置場等になつているために容易にはいかなかつたよ うである。

馬場殿仮屋等作事、進官領悉以越智方之押領之間、目 代方下行無之故、番匠共不致其沙汰、材木共捨置之云 々、山域杣未到来分八、花山木不切用如例云々、所詮 就条々来廿七日祭礼不定、諸頭人迷惑云々、不便、且 神慮如何、可恐々々

馬場とくにその周辺には松などが植栽され、つぎのよ うにしばしば補植されることがあつたととを知りうる。 昨日馬場松小々植之、七鄉人夫召之 馬場松今日又少々植之了

此院南方馬場松、或一本或二本宛仰付之殖之者也、西 馬場同、䊍三十本計也

また馬場の掃除のとともつぎのようにみえている。 御成方宮井馬場掃除事、東中院大坊敷地之在家二仰付
之處、彼坊知行谷坊也、然而谷坊順覚法印当年田楽頭 蒷仕二、彼在家人夫召仕之間、可故實旨自龍花院方申 入之、仍免之了、門跡大儀之時八召仕之、則先年予田 楽頭敀仕時も召仕之了、今度順覚法印田楽頭之間故實 之、

1）尋尊大僧正記巻 44 文明 7 年 2 月 23 日

2) 平中行事絵巻

3）同184 文亀元年 4 月 5 日

4）尋尊筆大乗院領内指図部分 天理図書館蔵

5）尋尊大僧正記 巻 120 文明 17 年 7 月 24 日

6）同 157 明応 2 年10月 28 日

7) 同 157 明応 2 年 10 月 29 日

8）同 73 文明 6 年 10 月 29 日

9）同 91 文明11年11月21日

10）同 57 文明 2 年12月 8 日

11）同 57 文明 3 年 1 月 13 日

12）同 126 文明19年12月 5 日

13）同 42 實正 6 年 8 月 6 日

iii）社寺境内地

社寺は元来宗教的な空間であり信仰の対象である。信 仰が一義的な意味をもつときそれは宗教空間であるが、 人間が社会生活を営む以上信仰は個人的な側面とともに 公共的な側面をもたざるをえず、とくに近代的個人の成 立以前においては個人は地緑的な集団性に媒介されての み自己を実現することができるのであり、生産・生活の 場をともにする人々が、一定の限られた数の社寺におい て求め実現させうる信仰は集落・地域社会的な基盤をも たざるをえず、それは同時に彼ら相互間の連带感を醉成 させるものであり、そこに信仰を媒介とする集落・地域 社会の広場の存在基盤があると考光られる。支配者首の 階級的・個人的な利益・個性と対応する傾向が大きい大 社寺においてはその個性か漒く残存する場合も多いが、

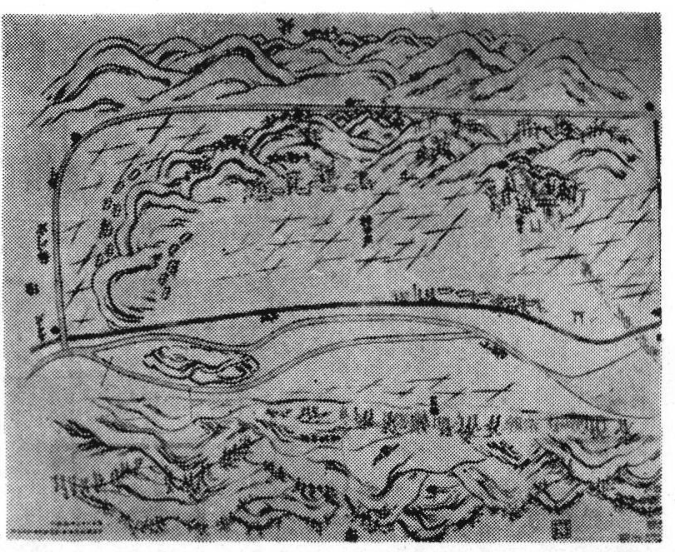

図一5 荘園の神社（紀伊国拤田荘） ${ }^{1)}$

荘園の東北部（八幡宮）、東南部に神社があり、農 家は山麓や川沿いの大道に沿つている 
集落・地域社会的基盤を有する小社寺はその個性を失 い、たんに鎮守、お宮、お堂などとよばれ、特殊な教義 を介するととなく集落民・地域社会構成員のそれへの参 加を許すにいたる。

さて、神社は集落における公共的な生活にかかわる度 合が高く、寺院は私的な信仰に関係するという理解があ る。本論ではいうまでもなく集落・地域社会の公共生活 にかかわる空間を問題とするのであり、個人の私的な信 仰にかかわる空間は考察のうえで一義的な意味を有しな い。それゆえここで問題とする寺院も集落・地域社会的 な公共性を獲得したそれであるか゚、このととは中世後半 期から近世初頭にかけて次にのべるような特別の意味内 容をもつととがある。

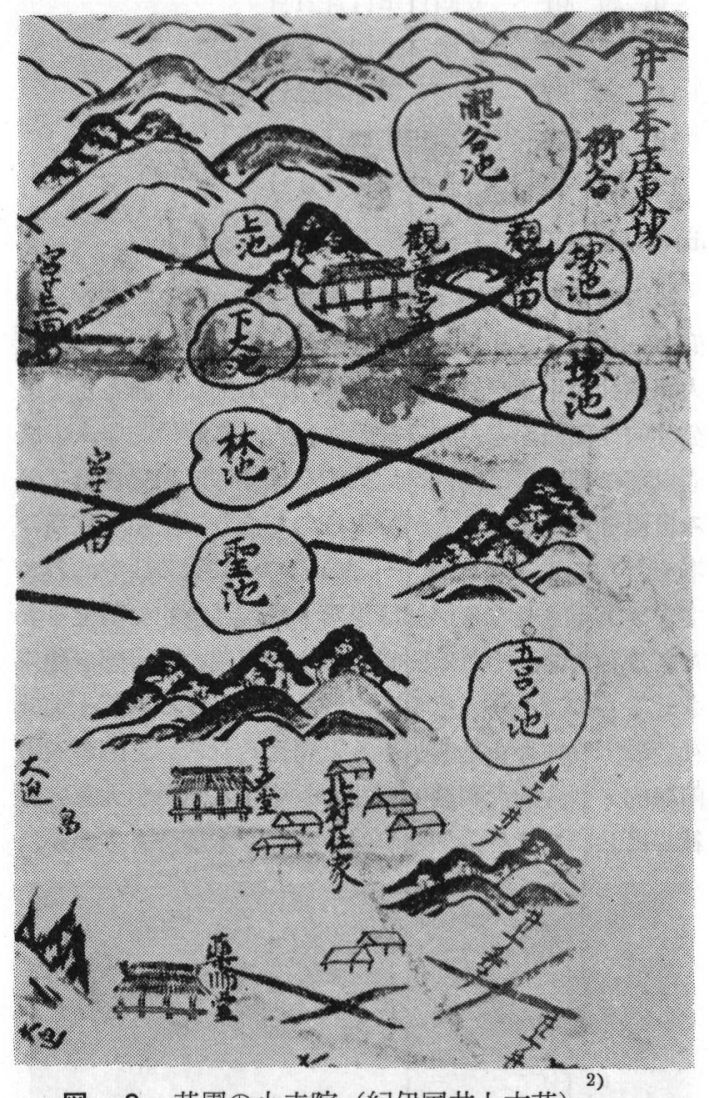

図一6 荘園の小寺院（紀伊国井上本荘）
すなわち、中世後半紀から近世初頭にかけて、集落・地 域社会の公共生活の実権を上首名主・閒閥的町人層か把 握したという同じ理由がそのまま神社の祭り・宮座など の利用において下層農民・町人層を蹯外するてとがあつ たが、そのように疎外された䅉は彼らの自立化を背景に 神社の利用に彼らの意志を反映させるべく努める一方、 他方で私的という一定の支配者側の了解のもとに小寺院 にわいて彼らの集会・レクリエーションの機能を充足さ せる合法性を獲得し、それを核とする小農・小町民の事実 上の公共生活を実現していく場合も多かつたのである。

他方で神社と寺院の性格それ自体も神仏習合などによ り同質化していく。

ことに集落・地域社会の公共生活にかかわる社寺の意 味があり、本論では社寺をそのような限定のもとに用い たい。

しかしすでにふれたように、中世においては、集落・ 地域社会の共同体的基盤をもつ社寺境内地の利用は一般 的には認められず、それの過渡的段階が時代の進展とと もにその性格を強くしていくのがみられるのみである。

荘園領主は荘園統制の必要上、本所系統の社寺を荘園 鎮守として歓請する場合が多く、それへの荘民の宗教的 ・レクリエーション的欲求の対象としての一定度の参加 を認め、それを通じて支配の一つの媒介環として意図す るととがあつたと考光られる。しかし中世前半期にあつ ては荘民はその身柄さえも領主・名主に隷属し彼らを通 してのみ自らを実現するてとができるのであり、その自 立性が低いとと、さらに空間的にも散村型の集落が一般 的であるととなどにより彼らの間の社会的関係は成立し にくく、そのような集落・地域社会的な社寺の利用のな され方にはおのずから限界があつたであろう。中世前半 期にあつては荘園と自然村落との関係が多様であること の必然として荘園鎮守の社寺と村落民との関係は一様で はない。集村型であつても散在入組型の荘園にあつては 極端な場合には荘園鎮守の社寺がその荘域外におかれる ことがあり、その地緑性を獲得できない場合がある。し かし一般的に集村型とくに一円集村型の荘園においては 集落民の相互間の社会的関係が比較的早期から成立し、 そのような結合の核としての社寺がみられる例もある。

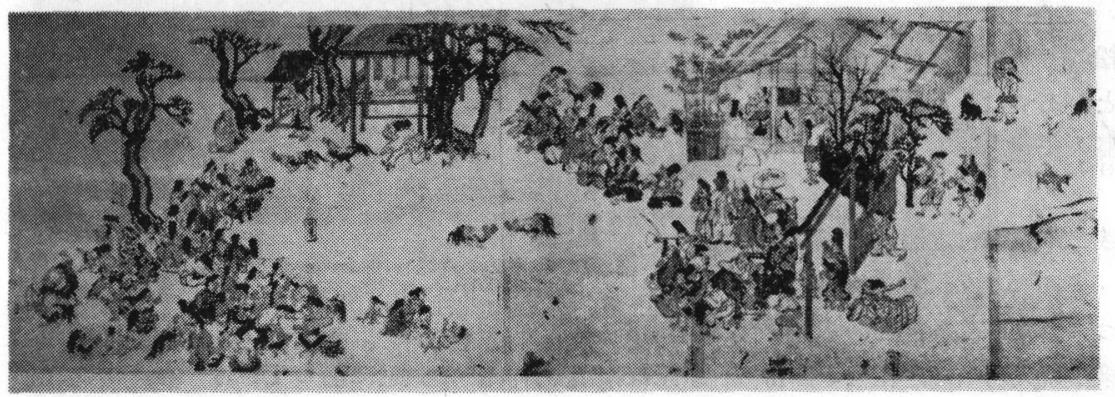

図一7 小社における闘鷄 
図-7、8は中世初期の小社寺における闘鷄、闘草の 様子を示したものであるが、中世初期においては社寺は 集落・地域社会的基盤をもつたとえば集会などを行う空

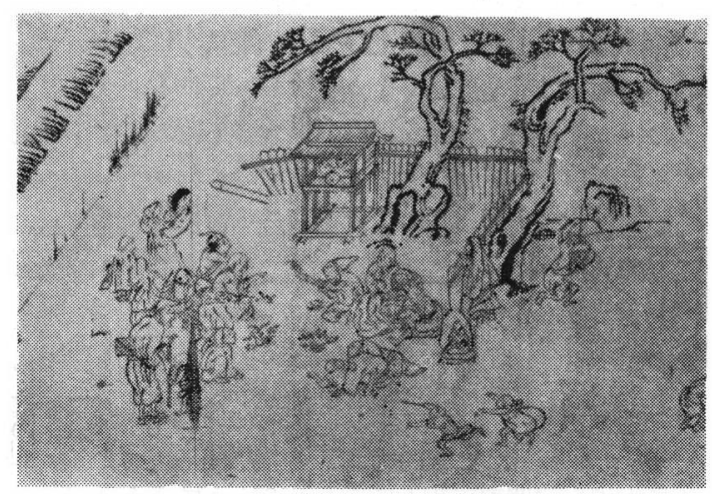

図一8 小社における闘草

間とはなつていず、小社寺の場合にも相互に結合された 人々の集会・レクリェーションの場ではなく、ある娛楽 を楽しむ偶然集まつた人々により形成される空間とい う色彩か強かつたと考えられる。

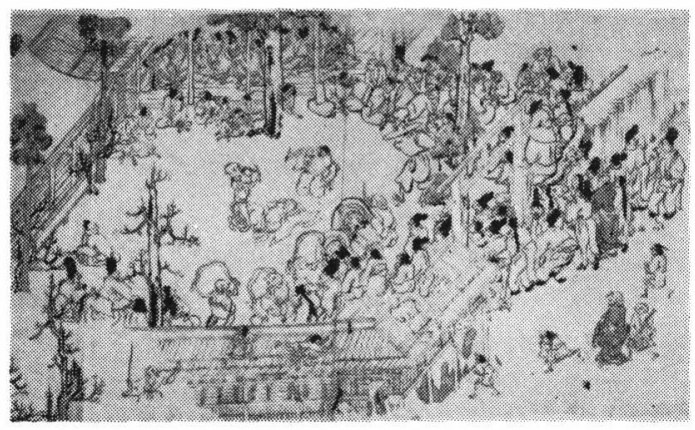

図一9神社における田楽

図一 9 は神社の田楽の舞の図であるが、貴人は屋内で、 庶民はそのわきから見物しているのがみえる。

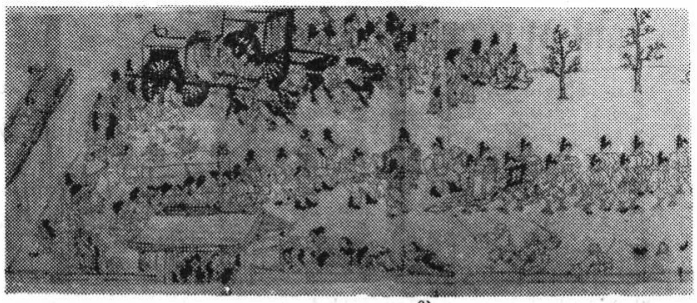

図一10 賀茂社の祭礼

図一10は賀茂社の祭礼の部分であるが、庶民は神人から 追いたてられ遠慮がちに見物している様子を知るてとが できる。てのように、比較的大きな社寺は庶民を疎外す る傾向が強かつたと考觉られる。
国・一揆・党などの荘園制を超える地緑的・同族団的 な組織の下に醎成されつつある地緑的村落においては、 荘園鎮守が当該領主・荘民のではなく、そのような村落 の結合の中心となるととがある。荘園鎮守の社寺が党・ 一癸等の結合の中心となりそれ本来の意味を失うにいた る場合もある。また地緑的村落はその結合の核として新 たに小社寺を設ける場合もある。てのような場合には一 般に地緑的村落の上層名主が彼らの結合の中心としての 宮座の場として機能する。

地緑的結合の典型である惣村・惣町結合の場合には地 緑的村落の発展・直接生産民の自立の過程において、宮 座は、そのうちに濃厚な身分関係を反映させながらも、 集落の特権的な層の独占からより広笓な構成員に解放さ れていく。こうして先進的な怱れおいては社寺の境内地 が村落民の重要事項の最高決議の集会場、あるいは日常 的なレクリェーション地として次第に定着していくので ある。奈良薬師堂惣郷では「毎事惣郷事卜ネ相催テ薬師 堂ヨ集会所二合沙汰評定スル也」とあり薬師堂か㥮鄉の 集会所であつたてとを知りうる。また社寺が集会の他に 集落・地域社会生活の必要に応じて種々の機能を充足し ていた。

南北郷於野上荒神䄀在之、則一万度初之、郷々在々云 々、祈雨也

これは奈良の南北鄉の祈雨のための祓が野上の荒神党に おいて開かれたととを示し、つぎにより奈良の平野辻堂 で猿楽が倠されたととを知りうる。

於平野辻堂自昨日手猿楽在之云々、京者也、両寺佳侶 見物之、甲乙人八銭宛出之云々、大群集也云々、 社寺境内地は平時にあつては寄合の場であつたり、鳥合 ・草合・猿楽・田楽等のレクリェーションの場であつた りするが、集落が外部から攻撃されたりあるいは一揆な どの積極的行動が起される場合にはその拪点となるとと がある。

布留社二引籠土民等今暁没落之間、則宮本発向、年預 共集会所 - 氏人共集会所 - 年預之庵室以下、或打破放 火了、物取共如雲霧、内山寺既以可令物取等乱入之条 難義迷惑之処、古市自身馳向致成敗之間、無為珍重、 山寺之安否此事也、河内之足軽共大勢催来云々、夕方 古市八田村二陣取之、丹後市郷悉以焼払之、社本々郷 これは大和山辺郡の布留惣郷々民が文明年間彼らの結合 の核とする石上布留明神に引籠り、領主前福寺に対峙し た一連の事件の一の寺院の記録であるが、布留社には各 郷より選出された「年預共」の集会所、「氏人共」の集 会所、および年預の庵室があつたととなどを知りうる。

神社の境内地は、乙れら社会的・政治的な集会の場と してのみでなく神事の場として重要であるてとはいうま でもない。春秋の新年・新嘗を中心とする祭り、境内地 
に仮屋を設けてそこにおいて共同飲食をする坐の催し、 定期的あるいは、祈雨などの不定期的な相撲会・猿楽な どは重要な神事であり、同時にレクリエーション的な側 面をもつていた。紀伊粉河寺の鎮守六所大名神の 6 月の 相撲会では東西に仮屋が設けられ、東および荒見の両村 人がそこに居並んで相撲を見物したという。

1）「国説白本文化史大系」5 小学館、1957

2）「国説日本庶民生活史」2 河出書房新社、1961 3),4),5),6)「年中行事絵卷」

7）原田伴彦：「日本封建都市政究」東大出版会、 1957

8）尋尊大僧正記 卷103 文明 14 年閏 7 月 9 日

9）同巻123文明18年 4 月 8 日

10) 同巻109 文明15年10月 8 日

11）豊田武：前掲書

iv） 市場

平安末期からの荘園領主・地方土豪の積極的な所領開 発、鎌倉期以後の集約耕作化なぞによる生産力の上向的 な発展にともない剩余が集積されるようになるが、これ の交換・流通の場としての市が、13世紀頃より多く出現 するにいたる。さらに年貢その他の貢納物の貨幣化の進 展注、領主・荘官などの支配的な層ばかりでなく広簙な 農民風をも方場への参加を余儀なくさせていつた。先進 地带を中心に鎌倉末期頃上り月 3 回の日切の定期市が形 成され、京都・奈良などの都市においては型日沐が立つ 場合もあつた。

书場は、領主・荘官の居住地、交通の要地、大社寺の 門前など流通・交換上の重要地点に設けられる場合と、 小社㠻の境内・闚前など集落・地域社会の人々の集まり やすいそのような基盤をもつ地点に設けられる場合があ つた。集落・地域社会の広場の観点からは後者がより重 要であるが、それの成立は南北朝・室町期頃よりみるこ とができる。

市場はいうまでもなく経済的な機能が第一義的である が、それの成立の前提としてまたは結果として、そこに 多くの人々が集まることを必要とするのであり、そのよ うな人々により䁔成される集会合・レクリエーションの 意義も大きくそてに広場的な機能が生ずることもある。 しかし中世においては、大きな都市以外では布場は地方 の中心という色彩か漒人、それを核としながら集落民・ 地域社会構成員相互間の日帯的な集会合・レクリエーシ ヨンを実現するという集落・地域社会的基盤をもつ市場 広場訬なかつたと考えられる。周辺農民にとつては、 むしろ、市場への参加は集落・地域社会生活の拘束から 解放される非日常的なレクリエーションの実現という期 待か強かつたと考えられる。

古代の市場洔専制国家体制下の大きな限定のもとに一
定度の府民の集会・レクリエーションの場としての機能 を有していたてとをすでにみた。中世においては市数の 飛躍的增加がみられるが、直接生産者首の自立化の過程 に対応して、そのような人々の意思の反映された迈站が 行われたり、あるいは領主のために設けられた市が一般 農民の啺になつていくような例もみられるようになり そのような市の広場的な機能の增大の条件の存在を推定 することができる。

東西八市八人集儿所也。其辺二行テ可何也卜云へバ。 下郎其所ノ形 $习$ 取テ市二行又。人極テ多カリト云へ ドモ。此レ二似タル者无シ。

これは中世初期の京の東西市が人々の集合する空間であ るととを示している。「国ノ上下ノ人聴聞ノ為二来り臨 テ市ヨ成テ居並タリ」「京中上中下見物二市ヨ成シタり」 「日本国之津門前成市」にみられるように「市成ス」 とは人々の多く集会合する形容であり市法元来人々のに ぎやか隹会合する空間であつたてとを知りうる。この ような市は盛り場的な魅力を持つていたのであろう。つ ぎのように女性を求めて市に出かける上屏民もあつた。

年中がいろ好みなりけるさかりに市にいきけり。中頃 はよき人々市に行きてなん色好むわざはしける。それ は故きさいの宮のでだち市に出たる日になんありけ

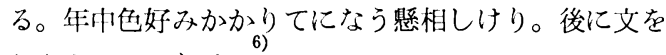
なんをてせたりける。

13世紀頃よりつぎのように甫場が各地に多くみられる ようになつた。

萓津の東宿の前をすぐれば、そこらの人あつまりて、 里もひびくばかりにののしりあへり。今日は书の日に なむあたりたるとぞいふなる。往還のたぐひ・手でと に空しから始づとも、女の「見てのみや人に語らん」 と詠める花のかたみには、やうかはりておばゆ。

捸津ノ国ノ難波ノ邊二行又。河ノ邊二俳趈スル間。市 ヨリ通ル人多カリ。

亀山は。慈恩寺。新福寺。阿弥陀寺。長福寺。第四筒 寺。各律院七堂みえたり。各々摍所々久東西市あり。 延文四年己亥六月五日、常楽寺市立始

このように宿場、門前などの都市的集落には市がさかん に立ちにぎわつたてとをみうるが、さらに、つぎのよう に村落においても同様であつたと推定される。

森の陰の一村里にて。市の商人の物さはがしきのみな り。

ひざおりといへる里に市侍り。

市場の空間については多くを知り光ないが、边場は计 庭あるいは市ノ庭ともいわれ、それが一定のひろがりを もつ空間に由来する可能性を示している。

盗人此ノ䀆タル絹习持テ。其ノ北息二有儿市 テ売ルニ。人有テ此レヨ買フ間。被盗テ後未ダ七日二 
不満ザル二。彼ノ市ノ庭二忽二猛キ風出来テ。其ノ絹 ヨ空二巻キ上テ。遙二南ヨ指テ吹持行ク。

市場には常設、仮設の市屋があるもの、あるいはそれの 全くないものなど種々である。

市庭在家後地用途事

合

二所臺反十代内茾代後地四百文 黒石二郎

○中略

以上拾肆間分

これは備中新見荘の市場であるが、10代つ゚つの市庭在家 が14軒並んでいたととを知ることができる。また一遍上 人絵伝の信州伴野市、福岡市の図、鹿田荘図、播磨国小 宅荘八日市などにみられる市では数個の在家が認められ る。市場の場所ははじめは折にふれて便宜な所に設けら れ可動的であつたが後には市場開設の場所がー定し市人 の定住もみられるようになり、在家が設けられるように なる場合も多かつたと考えられる。

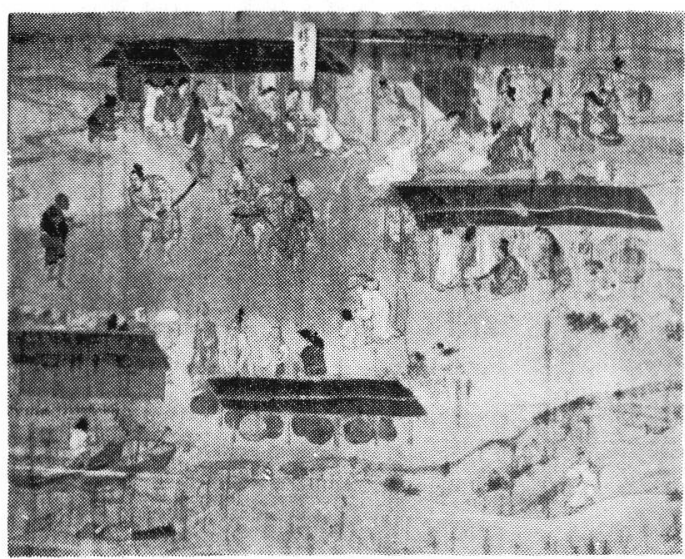

図一11 備前国福岡市

図一11は一遍上人絵伝の福岡市図である。数個の仮屋と それに囲まれた空地道路のふくらみよりなる市の形態を 知りうる。市場は交通の要衝にあつたのであろう、図の 手前には馬や船がみえる。また地域の情報中枢としての 機能をも有していたのであろう。妻を上人に伏仏された 男が怒つて上人の居所を知る情報を求めて市にやつてき たのであろう、そこで上人を見つけ切りつけようとして いるのである。

図一12は奈良南市図である。南市は北市とともに中世 前半期においてすでにみられたが長禄年間には「近来両 門市目然に無正体ナリ了」となり文明年間には堂敷を除 き開墾されてしまつた。四周は街路で囲まれ、方 1 町の 正方形をなし中坐にはつぎのような夷社が鎮座し、それ を中心に市仮屋が並んでいたのであろう。

南市恵美須社
乾元元年九月祭之

境内東西四間一尺、南北三間六尺三寸

市場の守護神としては夷社・市形島姫社が祭られるとと が多く常楽寺、奈良の南北市・高天市では前者を若狭の 倉見荘の実検田目録注文（永仁 3 年）にでてくる市では 後者を祭つている。

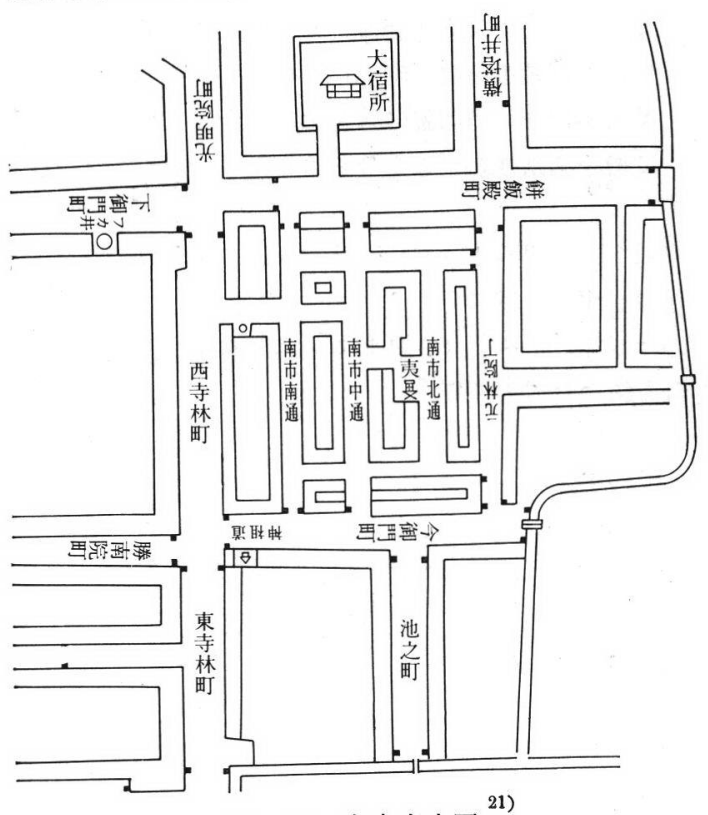

図一12 奈良南市図

市場ではこのような市神を中心に市祭が行われたが、 つぎのように田楽・猿楽などの神事が行われるととも多 く人々が群集した。

南市祭、九月四日同於禅定院在之田楽也、同予小五月 参申、新市始也

一延文四年己亥 六月四日、常楽寺市主始如法繁昌酒一瓶安為 拝殿座々下行惣寺学 同日擬市祭引遷於三経院前六月会之 両座猿楽仕、両産共三石下斗施給了、総之沙汰、五月 十二日新市之地引同上云 ○中略

一延文五年庚子十一月廿日、常楽寺市ノ祭於市場夷前 在之、楽頭中小路座楽師田楽奈良之新座田楽一円二参 勤、如法殊勝、禄物三貫文給了、料足八市 刀爾任料少分加 ○下略

その他、市でも鳥合・草合、博奕などの催しも多く行わ れ人々か群集したであろう。またつぎのように煊嘩の記 述も多くみえている。

於中市座喧嘩、被邹両方云々、於東大寺円城坊喧嘩事 在之又古市披官人自木津方召取之、以外事共今日在之 元興寺郷北室郷住人与傳害人於中市喧嘩了、仍鹞六方 中市二使付之云々

咋日於辰市結戒喧嘩在之死者両人一人八堀披官人也、 一人八沙汰手八結戒之太郎士衛門下人ナリ。 ○下略 
とのような市への庶民の参加は、室町・戦国期に入つ て著しく活況を呈してくる。つぎのように市の出る日に 同好を求めて市屋形にて飲酒を行うという市でのレクリ ェーション・交歓形態の存在を知りうる。

かやうに候者はあべ野のあたりに住るする者にて候。 けふは安部野の市にて候程に罷り出でばやと存じ候。 又いづくともしらず若き男来り某が酒を愛する者の候 けふも彼者を待たばやと存じ候。○中略 卮へきく白 楽天が作りし酒功讃の琴詩酒の友今にしられて市屋形 に樽を据总さかづきをならべてよりくる人を待ち居た り。

市場では領主側より高札が掲げられる場合も多いが、つ ぎは必ずしも市場での例ではないが、庶民が彼ら相互間 のコミュニケーション実現のために高札などを掲げる場 合もあつたであろう。

一人出てよきむすめを以たとゆふ。うちくらひ高き人 をむ子にせんとて高ふだたつる。

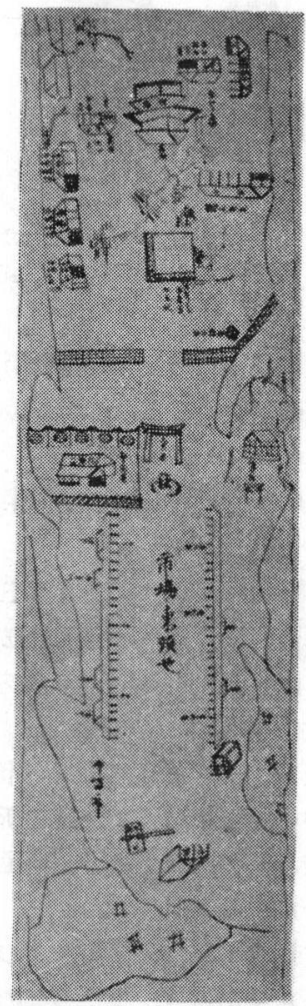

図一13 豊前国宇佐神宮放会殿社頭市 ${ }^{29}$

図一13は豊前国水崎村にある宇佐神宮放会殿の社頭の市
場である。毎年 8 月15日に行われる放生会には大鳥居前 の通路の南北両側に仮小屋が設けられ、そこに唐物産が 3 座づつ、その後方に酒屋や茶屋・千馬市などがあり、 また市場の管理者としての目代がみえる。こてに戦国期 の市場の空間形態を一定度知るととができる。

1 ) 豊田武：「増訂中世日本商業史の研究」岩波書店 1966

2) 今昔物語巻 $24 \quad 3$ ) 同巻 20

4) 同巻28 5) 大塔軍記

6) 大和物語上 7 ) 東関紀行

8 ）今昔物語 巻12 9) 宇長手記大永 2 年

10）嘉元記 11）なぐさめ草

12）廻国雑記 13）今昔物語 巻17

14）東寺百合文書夕（清水三男「日本中世の村落」）

15）豊田武前揭書 16）一遍人絵詞

17）小野晃嗣：『中世に於ける門前市場』(「史学雑 誌 Vol. 45 No.4)

18）小野晃嗣前掲書、尋尊大僧正記巻 154 明応 2 年 3 月 8 日

19）小野晃嗣前掲書、一乗院文書 10

20）豊田武同

21）小野晃嗣前掲書原図

22）小野晃嗣前掲書 23）嘉元記

24）尋尊大僧正記巻 72 文明 6 年 7 月 2 日

25）同 75 文明 7 年 6 月 26 日

26）同108 文明15年 7 月17日

27）『松蟲』(「謡曲集」)

28）『高ふだむ子』(「狂言集」)

29),30）「図説日本文化史大系」7 小学館、 1957

\section{Summary}

This is a study on the spaces as the Squares in the Middle ages.

In part 2, the relations of the Spaces as the Squares and the formative process of the socioeconomic conditions which the Squares are able to exist on are studied.

In part 3, the examples of such spaces such as the courtyard places, the riding grounds, the precincts of the shrines and the temples and the market places are tried to be studied.

(45.4. 20 受付) 